\title{
AKTIF YAŞLANMA BAĞLAMINDA YAŞ DOSTU KENT KAVRAMI
}

Betül TAMKOÇ ${ }^{1}$

Ömer Faruk BİLGİN ${ }^{2}$

\author{
$\ddot{O} z$
}

Endüstrileşme, kentleşme, bilimde ve teknolojide kaydedilen ilerlemeler gibi etkenler sonucunda doğum oranları azalmakta ve doğuşta beklenen yaşam süresi artmaktadır. Bunun doğal bir sonucu olarak dünya nüfusu giderek artan bir hızla yaşlanmakta ve toplam nüfus içerisinde yaşlı nüfus oranı artmaktadır. Demografik yapıda yaşanan bu değişimler artan ömrün insan onuruna yaraşır bir şekilde yaşanması için küresel ölçekte çözümler üretilmesini ve politikalar geliștirilmesini gerektirmektedir. Bu durum ulusal ve uluslararası ölçekte birçok kuruluşu harekete geçirmiştir. Bu kapsamda yapılan toplantılarda yaşlanma olgusu çok boyutlu olarak ele alınmış olup yaş̧ı bireylerin refahını geliştirmeye yönelik çeşitli kararlar alınmıștır. Bu bağlamda Dünya Sağlik Örgütü (DSÖ) tarafından 2002 yılında gelişmekte olan ülkeleri desteklemek ve yaşlanan dünyada sağlık ve sosyal alandaki politikaları güçlendirmek için Aktif Yaşlanma Politika Çerçevesi yayınlanmıştır. Ancak toplumdaki tüm bireylerin topluma etkin ve tam katılımının fiziksel ve sosyal çevrede bir düzenleme yapılmadan mümkün olamayacağından hareketle aktif ve sağlıklı yaşlanmayı amaçlayan Yaş Dostu Kentler (Age Friendly Cities) Projesi hayata geçirilmiștir. Bu çalıșmada yaş dostu kentlerin aktif yaşlanma bağlamında değerlendirilmesi amaçlanmaktadır. Bu kapsamda öncelikle yaşlanan nüfus ve kentleşme konuları ele alınmıştır. Daha sonra yaş dostu kent kavramı açıklanmış olup dünyada ve Türkiye'de yaş dostu kent uygulamaları aktif yaşlanma bağlamında değerlendirilmiş ve çıkarımlarda bulunulmuştur.

Anahtar Kelimeler: Yaşlılık, Kentleşme, Aktif Yaşlanma, Yaş Dostu Kent.

\footnotetext{
'Aile, Çalışma ve Sosyal Hizmetler Uzmanı, Aile, Çalışma ve Sosyal Hizmetler Bakanlığı, Engelli ve Yaşlı Hizmetleri Genel Müdürlüğü, E-Posta: betultamkoc@gmail.com ORCID: 0000-0001-5091-5813

${ }^{2}$ Daire Başkanı, Aile, Çalışma ve Sosyal Hizmetler Bakanlı̆̆ı, Engelli ve Yaşlı Hizmetleri Genel Müdürlüğü, E-Posta: ofarukbilgin@hotmail.com ORCID: 0000-0002-3626-4847
}

TAMKOÇ, B., BİLGİN, Ö. (2020). Aktif Yaşlanma Bağlamında Yaş Dostu Kent Kavramı. Sosyal Politika Çalışmaları Dergisi, “Erişilebilirlik” Özel Sayısı Cilt 2, 211-226. DOI: 10.21560/spcd.vi.816372 


\title{
THE CONCEPT OF AGE FRIENDLY CITY IN THE CONTEXT OF ACTIVE AGEING
}

\begin{abstract}
As a result of factors such as industrialization, urbanization, advances in science and technology are decreasing in the world and life expectancy at birth increases. As a natural consequence of this, the world population is ageing at an increasing rate and the population ratio is increasing. These changes in the demographic structure require the development of global solutions and policies in order to live in a way that is worthy of human dignity. This situation has mobilized many institutions at national and international scale. In the meetings held within this scope, the phenomenon of ageing was handled in a multidimensional way and various decisions were taken to improve the well-being of elderly people. In this context, the Active Ageing Policy Framework was published by the World Health Organization (WHO) in 2002 to support developing countries and to strengthen health and social policies in the ageing world. However, the Age-Friendly Cities (Age-Friendly Cities) Project, which aims active and healthy ageing, has been put into practice, since it is not possible for all individuals in the society to participate effectively and fully in the society without a regulation in environmental architecture. In this study, it is aimed to evaluate age-friendly cities in the context of active ageing. In this context, the ageing population and urbanization issues were primarily discussed. And then the age friendly city concept was explained and age friendly city practice in the world and in Turkey evaluated in the context of active ageing and inferences have been made.
\end{abstract}

Keywords: Ageing, Urbanization, Active Ageing, Age Friendly City. 


\section{GİRIŞ}

Gelişim evrelerinden biri olan yaşlılık; biyolojik, psikolojik ve sosyal olmak üzere çok yönlü ele alınması gereken bir dönemi ifade etmektedir. Dünya Sağlık Örgütü (DSÖ) ise yaşlılık kavramını, biyolojik olarak aşamalı bir şekilde moleküler ve hücresel olarak deformasyon sonucunda fizyolojik olarak hareketlerin kısitlanması, hastalık riskinin artması ve bireysel kapasitenin azalması olarak tanımlamaktadır (WHO, 2015, s. 25). Eğitim ve çalışma koşullarındaki iyileşmeler, sağlık sistemindeki gelişmeler ile insanlar daha iyi yaşam koşullarına sahip olmaktadır. Bunun etkisiyle de dünya genelinde doğum oranları azalmakta ve doğuşta beklenen yaşam süresi artmaktadır (OECD, 2016, s. 114; Karadağ ve Akyıldız, 2019, s. 571). Bunun sonucunda yaşlı nüfusun toplam nüfus içerisindeki oranı giderek artmaktadır. Birleşmiş Milletler Nüfus Birimi nüfusun yaşlanmasının hızla artarak devam edeceğini ve düşük doğum oranlarının bu artışı daha da ön plana çıaracağını belirtmektedir (UNECE Working Group on Ageing, 2015, s. 2).

Bugün dünya nüfusunun $\% 9,1$ 'ini 65 ve üzeri yaş grubunda bulunan insanlar oluşturmakta olup bu oranın 2050 yılına gelindiğinde $\% 15,9$ olacağ 1 öngörülmektedir (UN Department of Economic and Social Affairs, 2019, s. 18). Bunun doğal bir sonucu olarak kentsel alanlarda yaşayan yaşlı nüfusta da bir artış meydana gelmektedir. 2050 yılına kadar kentsel yaşlı nüfusun ikiye katlanarak \%11'den \%22'ye yükselmesi beklenmektedir. Bu durum gelişmekte olan ülkelerdeki nüfusun \%25’inin kentsel alanlarda yaşayacağ gelmektedir (Ferreira, 2010, s. 55). Türkiye'de ise yaşlı nüfus oranı 2019 y1lı itibariyle \%9,1'e ulaşmış olup bu nüfusun \%1,2'si kırsal alanlarda, \%7,9 ile büyük bir çoğunluğu ise kentsel alanlarda yaşamaktadır (TÜİK, 2020b).

Nüfusun yaşlanması ve kentleşme hem insanlığın bir başarısı hem de zorlukları olan bir durumdur. Bilgi, beceri ve tecrübeleri ile 1996 tarihli Brezilya Yaşlanma Deklarasyonu'nda da belirtildiği üzere yaşıı bireyler aileleri, toplum ve ekonomi için bir kaynaktır (WHO, 1997, s. 21). Geçmiş ile gelecek arasında köprü olan yaşlı bireyler, fiziksel çevrede meydana gelen değişimlerden en çok etkilenen gruptur. Fiziksel ve sosyal çevre yaşlı bireylerin topluma katılımı konusunda en belirleyici faktörler olup bireylerin kapasitesini etkilemektedir. Yaşlı bireylerin, sosyal ve toplumsal bağlarını sürdürebilmeleri ve yeni ilişkiler kurabilmeleri güvenli bir yaşam çevresine bağlıdır (Tutal ve Üstün, 2009, s. 2). 
Erişilebilir çevreler yaşlı bireylerin bağımsılılıklarını arttırarak aktif bir şekilde yaşamlarını kolaylaştırırken olumsuz çevre koşulları yaşlı bireylerin aktifliğini negatif yönde etkilemektedir.

Tüm yaş gruplarını kapsayıcı ve sürdürülebilir kentler insan onuruna yaraşır bir yaşam için temel unsurdur. Kentsel alanların tüm yaş grupları için daha yaşanabilir hale getirilmesi, aktif ve sağlıklı bir şekilde yaş almak için uygun fiziksel ve sosyal ortamların oluşturulması amacıyla Dünya Sağlık Örgütü (DSÖ) tarafından yaş dostu kent kavramı geliştirilmiştir. Bu çalışmada yaş dostu kent kavramı ele alınacak olup yaş dostu kent uygulamalarının aktif yaşlanmaya etkisi değerlendirilecektir.

\section{YAŞLANAN NÜFUS VE KENTLEŞME}

Dünya genelinde yaşlı bireylerin sayısında bir artış mevcuttur. Hemen her ülkenin toplam nüfusu içerisinde yaşlı olarak tanımlanan 65 ve üzeri yaş grubundaki bireylerin oranı artmaktadır. Yaşlı nüfusta yaşanan bu artış ile kentte yaşayan yaşlı nüfusta da bir artış gözlemlenmektedir. Bu durumun doğal bir sonucu olarak nüfusun yaşlanması ve kentleşme yirmi birinci yüzyıla damgasını vuran iki önemli kavram olarak karışımıza çıkmaktadır.

Birleşmiş Milletler Ekonomik ve Sosyal İşler Bölümü, 2019 yılı itibariyle dünya üzerindeki nüfusun $\% 9,1$ 'ini 65 ve üzeri yaş grubundaki bireylerin oluşturduğunu belirtmekte ve nüfus projeksiyonlarına göre bu oranın 2030 yılında \%11,7’ye tırmanacağını öngörmektedir. Bu durumun iki temel sebebi ortalama yaşam süresinin artması ve doğum oranlarında meydan gelen azalmadır. Bilim ve teknolojide yaşanan gelişmeler, sağlık sistemlerindeki ilerlemeler ile yaşam kalitesindeki iyileşmeler doğuşta beklenen yaşam süresinde bir artışa neden olmuştur. Dünya genelinde doğuşta beklenen yaşam süresi 1990 yılından 2019 yılına kadar 8 yıl daha artarak 72,6’ya ulaşmıştır. Bu durumun tersi olarak doğurganlık oranları sürekli bir azalma eğilimi göstermektedir. Nitekim 1990 yılında 3.2 olan kadın başına ortalama doğum sayısı 2019 yılında 2.5'e düşmüştür (UNDESA, 2019b, s. 18-28).

Türkiye'de de tüm dünyada olduğu gibi doğurganlık hızı azalmakta, doğuşta beklenen yaşam süresi artmakta ve nüfusun yaşlanması deneyimlenmektedir. 2019 yılı itibariyle 7 milyon 550 bin 727 kişi ile toplam nüfusun \%9,1'ini yaşlı bireyler oluşturmaktadır (TÜİK, 2020a). 
Artan bu nüfusun büyük bir kısmı ise kentsel alanlarda yaşamaktadır. 1950 ve 2018 yılları arasında dünyanın kentsel nüfusu tahmin edilen rakamlara göre dört kattan daha fazla artmıştır. 1950 yılında dünya nüfusunun \%29,6’sı kentsel alanlarda yaşamakta iken 2018 yılında bu oran \%55,3 olmuştur (UNDESA, 2019a, s. 9). İlerleyen ylllarda da kentsel nüfusun artmaya devam edeceği ve 2050 yılına kadar kentsel nüfusun yaklaşık olarak iki katına çıkacağı öngörülmektedir (WHO, 2018, s. 1). Şehirler sürdürülebilir kentsel gelişimin önemli unsurları olup dünya üzerindeki yaşlı nüfusun $\% 43,2$ 'sine ev sahipliği yapmaktadır (OECD, 2015, s. 18).

Türkiyede de kentleşme oranları sürekli olarak artış göstermiş olup 1950 yılında \%24,8'den 2018 yılında \%75,1'e yükselmiştir. Bu oranın artmaya devam edeceği ve 2050 yılında \%86’ya ulaşacağı öngörülmektedir (UNDESA, 2018).

Kentsel nüfusta meydana gelen bu artış, yaşlanan toplumun sorunlarını daha da görünür hale getirmektedir (Brdulak, 2017, s. 66). Yaşam beklentisindeki artış ile yaşlılık dönemine eşlik eden kronik hastalıklarda da bir artış meydana gelmektedir (Arslantaş vd., 2005; Bilir, 2006). Bu hastalıklar bireylerin günlük yaşam aktivitelerini yerine getirirken zorlanmalarına sebep olmakta ve yaşam kalitelerinin düşmesine neden olmaktadır (Güler vd., 2009, s. 368). Bu durum yaşlı bireylerin günlük yaşam aktivitelerini yerine getirirken bir başkasının yardımına ihtiyaç duyar hale gelmelerine neden olmakta ve yaşanılan çevrenin değişen ihtiyaçlara göre dizayn edilmesini gerektirmektedir. Yaş dostu kent kavramı da bu ihtiyaçtan dolayı ortaya çıkmış bir kavramdır.

\section{YAŞ DOSTU KENT KAVRAMI}

Nüfusun yaşlanması insanlığın bir başarısı ve gelişmişlik göstergesidir (UNDESA, 2019c; European Commission, 2014; WHO, 2002; Zhu vd., 2019). Ancak yaş alma ile; fiziksel kapasitede, eş ve yakın çevreden insanların kaybı ile psikolojik ve sosyal durumda, emeklilik sonrası gelir kaybı ile ekonomik durumda meydana gelen gerilemeler yaşlı bireylerin aktif ve bağımsız bir şekilde toplumsal hayata katılmalarını zorlaştırmaktadır. Bütün bunlar yaşlı bireylerin bağımlılıklarını arttırmakta, yaşam kalitelerini düşürmekte ve sürdürülebilir bir yaşlanma için elzem olan aktif yaşlanmanın geliştirilmesini engellemektedir. 
Toplumsal değerlerimiz olan yaşlı bireylerin, bağımsız bir şekilde toplumsal hayatta var olmaya devam etmeleri ancak kapsayıcı ve sürdürülebilir yaşam alanları oluşturularak mümkün kılınabilir.

Yaş dostu kent kavramı da bu gerçekten hareketle üretilmiş bir kavram olup Dünya Sağlık Örgütü (DSÖ) tarafından, yaşlıların aktif katılımını destekleyen, yapı ve hizmetleri yaşlılar için erişilebilir kılan ve yaşlılar için güvenli ortamlar oluşturabilen kent olarak tanımlanmaktadır (WHO, 2007, s. 1). Farklı bir tanımda ise yaş dostu kent kavramı, aktif yaşlanma için olanak sunan, yaşanabilir, güvenli ve temiz bir çevre olarak ifade edilmiştir (Aslan, 2015, s. 26). Gorman ise yaş dostu kentleri; güvenli, düşük maliyetli ve uygun ulaşım imkanları sunan mekanlar olarak tanımlamıştır (Gorman vd., 2019, s. 2).

Genel bir ifade ile aktif yaşlanmayı sağlamak için bireylerin sağlıklı ve güvenle yaşamasına olanak sağlayan çevre olarak tanımlanabilecek olan yaş dostu kentin bileşenleri ise:

- Diş mekânlar ve binalar,

- Ulaşım,

- Konut,

- Sosyal katılım,

- Toplumsal yaşama dâhil olma ve toplumun yaşlıya saygısı,

- Vatandaşlık görevini yerine getirme ve işgücüne katılım,

- Bilgi edinme ve iletişim,

- Toplum desteği ve sağlık hizmetleri olmak üzere sekiz tanedir (WHO, 2007, s. 8).

Yaş dostu çevreler oluşturma fikri çeşitli politika çerçevelerinde ve programlarda kendine yer bulmuş olup birçok politika çerçevesine yaş dostu kentler oluşturmaya yönelik hedefler eklenmiştir. Bunlardan biri de Ocak 2016 tarihinde yürürlüğe giren ve on beş yıl boyunca Birleşmiş Milletler Kalkınma Programına rehberlik edecek olan yoksulluğu ortadan kaldırmayı, dünyamızı korumayı ve tüm insanların barış ve refah içerisinde yaşamasını sağlamayı amaçlayan 2030 Sürdürülebilir Kalkınma Hedefleri arasında yer alan "sürdürülebilir şehirler ve toplumlar" hedefidir. 11 numaralı "sürdürülebilir şehirler 
ve toplumlar" kalkınma hedefinin 7 tane alt hedefi ise herkes için erişilebilir ve güvenli konut, herkes için erişilebilir ve sürdürülebilir toplu taşıma olanakları, sürdürülebilir ve kapsayıcı şehir planlaması, kültürel mirasın korunması, yoksul ve savunmasız durumdaki insanları afetlerden korumak, atık yönetimine özen göstererek olumsuz çevresel faktörleri azaltmak ve özellikle kadın, çocuk, engelli, yaşlı bireyler için güvenli kapsayıcı ve yeşil çevreler oluşturarak bu alanlara erişimi sağlamak olarak belirlenmiştir (UNDESA, 2020).

Yaşlı bireyler için erişilebilir çevrelerin önemine vurgu yapan uluslararası bir diğer belge de 2016 yılında düzenlenen Birleşmiş Milletler Konut ve Sürdürebilir Kentsel Gelişim Konferansı'nda kabul edilen Yeni Kentsel Gündem'dir. Bununla birlikte üye devletler nüfusun yaşlanmasının sosyal, ekonomik ve mekanla ilgili sonuçlarına göre önlemler alacaklarını, sürdürülebilir, insan merkezli, yaşa ve cinsiyete duyarlı konutlar, ulaşım imkanları ve yeşil alanlar oluşturacaklarını taahhüt etmişlerdir (UN, 2017, s. 5).

\section{AKTIF YAŞLANMANIN GELIŞTİRILMESINDE YAŞ DOSTU KENT UYGULAMALARI}

Aktif ve sağlıklı bir yaşlılık döneminden bahsedebilmek için anahtar kavramlar bağımsızlık ve katılımdır. Nitekim bu iki kavram 16 Aralık 1991 tarihinde Birleşmiş Milletler Genel Kurulu'nda kabul edilen Birleşmiş Milletler Yaşlılık İlkeleri arasında da yer almaktadır (ASPB Engelli ve Yaşlı Hizmetleri Genel Müdürlüğü, 2014).

Bağımsızlık ilkesi gereğince, yaşanılan sosyal çevre yaşlı bireylere kapasitelerini geliştirebilecekleri fırsatlar sunmalı, mümkün olduğunca yaşlı bireylerin kendi evlerinde ve sosyal çevrelerinde yaşamaları sağlanmalı, yaşlı bireyler gelir getirici işlerde çalışabilmelidir.

Katılım ilkesi gereğince ise, yaşlı bireyler toplumsal alanda ilişkilerini sürdürebilmeli, bu alana dair politikaların geliştirilmesinde her aşamada aktif olmalı, tecrübelerini genç kuşaklar ile paylaşmalı ve ilgileri doğrultusunda topluma katkıda bulunmalıdır (Buz vd., s. 391). Bu ilkelere uygun bir yaşlanma sürecinin sağlanması için gerekli koşul ise uygun fiziksel ve sosyal ortamların, yani yaş dostu kentlerin oluşturulmasıdır.

Kentsel nüfusun yaşlanması, şehirlerin daha yaş dostu hale gelmesini gerektirmektedir (Hoof vd., 2018, s. 12). Bu gerçekten hareketle yaşlı bireylerin 
toplumsal alanda var olmaya devam etmesini sağlamak ve yaş dostu kentleri yaygınlaştırmak için 2005 yılında Brezilya’da gerçekleştirilen 18. Dünya Gerontoloji ve Geriatri Kongresinde Yaş Dostu Kent (Age Friendly Cities) Projesi tasarlanmıştır (WHO, 2007, s. 1). 2007 yılında ise Dünya Sağlık Örgütü (DSÖ) tarafından yaş dostu bir kentin sahip olması gereken nitelikleri belirlemek için "Küresel Yaşlı Dostu Şehirler Rehberi” oluşturulmuştur. Bu rehber ile hem kavram daha somut bir hale getirilmiş hem de yaş dostu çevreler için evrensel standartlar geliştirilmiştir. 2010 yılında da bu uygulamanın daha görünür hale getirilmesi amaciyla "Yaş Dostu Şehirler Küresel Ağı" oluşturulmuştur (Caner vd., 2013, s. 10). Bu sayede yaş dostu kent olarak kabul edilmenin prestij ve gelişmişlik göstergesi olması nedeniyle ülkelerin bu konuya daha özverili yaklaşmaları sağlanmıştır. Güncel rakamlara göre 2020 yılı itibariyle dünya genelinde 41 ülkeden 1000 şehir ve topluluk bu ağa dahildir (WHO, 2020a).

Kentsel mekanlarda yaşlı bireylerin erişilebilirliğini sağlamak üzere gerçekleştirilen uygulamaları temelde barınma, ulaşım ve kamusal alanlar olmak üzere üç kategoride incelemek mümkündür. Bu üç alanın hepsinde de erişilebilirliğin sağlanması yaşlı bireylerin bağımsız bir şekilde yaşamlarına devam etmeleri ve toplumsal alanda var olmaları için elzemdir.

Barınma: Yaşlı bireylerin yaşadıkları evin koşulları bireyin hayat kalitesinde belirleyici olmaktadır. Olumlu erişilebilir ve güvenli bir ev yaşlı bireyler için daha sağlıklı bir hayat anlamına gelirken olumsuz koşullara sahip bir evde yaşamak yaşam kalitesini düşürmektedir. Nitekim Dünya Sağlık Örgütü (DSÖ) de güvenlik ve iyilik hali için barınmanın gerekliliğine vurgu yapmakta uygun bir evde yaşamak ile topluma katılım ve sağlık hizmetlerine erişim arasında bir ilişki olduğunu belirtmektedir (WHO, 2007, s. 30).

\section{Donostia'da Akıllı Evler, San Sebastián, İspanya:}

İspanya'da San Sebastián Şehri’nde çok stratejik bir konumda bulunan Lugaritz, yeni bir konut kompleksidir. Bu kompleks daha yaş dostu bir çevre için mahalle bağlantısını iyileştirmeyi ve yeni sosyal uyum yöntemleri yaratmayı amaçlamaktadır. Projenin temelde hedef kitlesi yerinde yaşlanan çiftlerdir. Bu evlerde hizmetler bireysel ihtiyaçlara göre sunulmakta olup bireyler ihtiyaçlarını ve taleplerini akıllı cihazlar ve sensörler aracılı̆̆ıyla iletmektedir (WHO, 2020b). 
Ulaşım: Aktif yaşlanmanın temel ögesi aktif seyahattir. Yaşlı bireylerin bir başkasının desteğine ihtiyaç duymadan dışarı çıkabilmesi için ulaşım olanaklarının uygun maliyetli olması, erişilebilir olması, emniyetli ve yaş dostu olması çok önemlidir.

\section{Malta'da Silver T ve Scooter Hizmeti:}

Uzun mesafelerde yürümekte güçlük çeken kişiler, ailelerine veya arkadaşlarına bağımlı olmaksızın günlük yaşama dahil olmak, temel yaşam aktivitelerini yerine getirebilmek için kişiselleştirilmiş bir ulaşım ihtiyacı duymaktadırlar. Malta'da uygulamaya konulan Silver T ve Scooter hizmetinin de çıkış nedeni daha kişiselleştirilmiş bir ulaşım hizmeti sunmaktır. Pazartesi'den Cuma'ya 07.00 ile 14.00 saatleri arasında çalışan Silver T servisi; banka, market, klinik, yerel meclis ve ibadethanelere gitmek isteyenlere ulaşım olanakları sağlamaktadır. Ancak bu hizmete erişmek için kişinin en az 2 gün, en fazla 1 hafta öncesinden rezervasyon yaptırması gerekmekte olup hizmet ücretsiz olarak sunulmaktadır. Başkent Valletta'daki elektrikli scooter hizmeti ise, hareket güçlügü çeken yaşlıların ücretsiz olarak bir scooter kiralamasına olanak sağlamaktadır. Bu hizmet kapsamında en fazla 3 saatliğine ve Valletta semtinde olmak koşuluyla scooter kiralanabilmektedir. Bu hizmet de Pazartesi'den Cuma'ya 07.00 ile 14.00 saatleri arasında çalışmaktadır. Scooter, otobüs terminali ya da Aile, Çocuk Hakları ve Sosyal Dayanışma Bakanlığı'ndan temin edilebilmektedir (UN, 2020, s. 15).

Kamusal alanlar: Kamusal alanların erişilebilir olması kaliteli bir hizmet sunumu için elzemdir. Ayrıca yaşlı bireyler için keyifli ve temiz bir çevrede yaşamak önemlidir. Temiz, güvenli kaldırımları ve sokakları olan şehirler insanların yaşam doyumlarını yükseltmekte ve hizmetlere daha kolay erişimi sağlamaktadır. Bu sayede sosyal yaşamı geliştirmekte ve kimlik duygusunu pekiştirmektedir.

\section{Erişilebilirlik Fonu Etkinleștirme, Kanada:}

Erişilebilirlik Fonu, yapı maliyetlerini ve yenileme projelerini destekleyen, Kanada toplumunda ve işyerlerinde engelli bireyler için fiziksel erişilebilirlik ve güvenliği geliştiren federal bir hibe ve katkı programıdır. Engelli bireyler, sıklıkla günlük yaşam aktivitelerine tam katılım ve içerme konusunda engellemeler ile karşılaşmaktadırlar. Fon, engelli kişilerin Kanada genelindeki 
topluluk alanlarına ve işyerlerine erişimini artıran uygun sermaye projelerine finansman sağlamakta ve bu da topluluk etkinliklerine, hizmetlerine ve programlarına katılma veya istihdam fırsatlarına erişim fırsatları yaratmaktadır (Government of Canada, 2020).

Türkiye'de de son yıllarda ulaşım, binalar ve diş mekânlara dair düzenlemeler ile kentsel alanlarda yaşam kalitesini arttırmaya yönelik yasal düzenlemeler yapılmakta ve politikalar hayata geçirilmektedir. Erişilebilir çevreler için yasal dayanaklar 3194 sayılı İmar Kanunu, 5378 sayılı Engelliler Hakkında Kanun, Erişilebilirlik İzleme ve Denetleme Yönetmeliği ve Ücretsiz veya İndirimli Seyahat Kartları Yönetmeliği'dir. 3194 sayılı İmar Kanunu, yerleşme yerleri ile bu yerlerdeki yapılaşmaların; plan, fen, sağlık ve çevre şartlarına uygun teşekkülünü sağlamak amacıyla çıkarılmıştır. 7/7/2005 tarihinde yürürlüğe giren Engelliler Hakkında Kanun'un geçici 2 nci ve 3 üncü maddeleri ile tüm kamu kurum ve kuruluşlarından, kamu kullanımına açık binalar ve açık alanlar ile toplu taşıma araçlarını, Kanunun yürürlüğe girdiği tarihten itibaren sekiz yll içinde engelliler için erişilebilir duruma getirmeleri istenmiştir. Erişilebilir çevreler için bir diğer önemli yasal düzenleme ise 20/07/2013 tarihli ve 28713 sayılı Resmî Gazete'de yayımlanarak yürürlüğe giren Erişilebilirlik İzleme ve Denetleme Yönetmeliği'dir. Bu yönetmelikte, kentlerde erişilebilir olması gereken yerler binalar, açlk alanlar ve toplu taşıma araçları olmak üzere üç gruba ayrılmıştır. Ayrıca yönetmelik kapsamında ulusal erişilebilirlik izleme sistemi kurulmuştur. Bu sayede kamu kurum ve kuruluşlarına ait mevcut resmî yapılar, mevcut tüm yol, kaldırım, yaya geçidi, açık ve yeşil alanlar, spor alanları ve benzeri sosyal ve kültürel alt yapı alanları ile gerçek ve tüzel kişiler tarafından yapılmış ve umuma açık hizmet veren her türlü yapılarda ve toplu taşıma araçlarında erişilebilirlik standartlarının uygulanmasının takip edilmesi sağlanmıştır.

Türkiye'de 65 yaş ve üstü bireyler, engelliler ve refakatçileri için şehir içi ve şehirlerarası otobüs, vapur, tren ve uçak gibi tüm toplu taşıma araçları indirimli veya ücretsizdir (UN, 2020, s. 15). Bu uygulamanın dayanağı 04/03/2014 tarihli ve 28931 sayılı Resmî Gazetede yayımlanarak yürürlüğe giren Ücretsiz veya İndirimli Seyahat Kartları Yönetmeliği'dir. Yönetmelik gereğince 65 ve daha üzeri yaş grubundaki bireyler ile engelli ve engelli refakatçileri için şehir 
içi, şehirlerarası, otobüs, vapur, tren ve uçak gibi ulaşım araçları indirimli ya da ücretsizdir (Ücretsiz veya İndirimli Seyahat Kartları Yönetmeliği, 2014).

Türkiye'de kentsel mekanların yaş dostu hale getirilmesi önemle üzerinde durulan bir konu olup bu amaca yönelik projeler devlet tarafindan da desteklenmektedir. Ülke çapında yaş dostu, aktif ve sağlıklı yaşlanmaya olanak tanıyacak alanların oluşturulması amacıyla Aile, Çalışma ve Sosyal Hizmetler Bakanlığı tarafından hayata geçirilen Yaşlı Destek Programı (YADES) hayata geçirilmiştir. Bu program kapsamında, kentlerde yalnız yaşayan ya da yakınları ile yaşayan fakat sosyal destek ihtiyacı içerisinde olan yaşlıların toplumsal hayata katılımını sağlamaya yönelik projeler desteklenmektedir. Destek sağlanan projeler kapsamında yaşlı bireylerin evlerinde yapılan tadilatlar neticesinde konutlar daha erişilebilir hale getirilmekte, oluşturulan gündüz hizmet merkezleri ile yaşlı bireylerin toplumsal hayata katılımı desteklenmekte, oluşturulan çağrı merkezleri sayesinde yaşlı bireyler ve ilgililerin 7/24 irtibatta kalması sağlanmaktadır. Bütün bu uygulamalar sayesinde yaşlı bireylerin sosyal içerilmesi sağlanarak insan onuruna yaraşır şekilde toplumsal hayata katılmaları desteklenmektedir.

\section{SONUÇ VE DEĞERLENDIRME}

Yaşlı bireylerin, tam bir iyilik hali içerisinde olması için temel unsur erişilebilir, destekleyici ve sürdürülebilir bir çevredir. Nitekim “özellikle engelli yaşlıların ihtiyaçları doğrultusunda bağımsız yaşamı teşvik edecek konut ve çevre tasarımları yapılması ve yaşlı bireyler için erişilebilir ve ulaşılabilir uygun maliyetli ulaşım olanaklarının geliştirilmesi” Madrid Uluslararası Yaşlanma Eylem Planı’nın taahhütleri arasında da yer almaktadır. Bu nedenle şehirler dizayn edilirken, şehirde yaşayanların yaşam kalitesini arttıracak şekilde tüm yaş gruplarının ihtiyaçları ve beklentileri dikkate alınmalıdır. Ancak çoğu şehir fiziksel olarak işlevsel olan sağlıklı vücut fonksiyonlarına sahip insanlar düşünülerek tasarlanmış olup yaşlı bireyler özellikle işlevsel yeteneklerini kaybettiklerinde ekonomik ve sosyal hayattan dışlanmaktadır.

Uygun bir şehir planlaması, yürüme mesafelerinin eğitim, sağlık ile yeşil alanların hizmet etki alanındaki nüfusun erişme mesafesinin topoğrafya, yapılaşma, yoğunluk, mevcut doku, doğal ve yapay eşikler dikkate alınarak planlanması (Mekansal Yapılar Yapım Yönetmeliği, 2014), şehir içerisinde 
serbestçe hareket edebilmek, bağımsız ve aktif olarak toplumsal hayata katılmaya devam edebilmek için anahtar rol oynamaktadır.

Giderek daha da yaygın bir hale gelen yaş dostu kentler bireylerin işlevselliğine katkıda bulunarak aktif yaşlanma için zemin hazırlamaktadır. Böylece fiziksel işlevselliğin azalması nedeniyle yaşanan sorunlarla bireyler daha kolay mücadele edebilmektedir. Yaş dostu kentler sadece fiziksel yapıda değil sosyal ve ekonomik açıdan da dönüşümü içermektedir. Yaş dostu bir kentte binalar kişilere göre dizayn edilmekte, toplu taşıma erişilebilir hale getirilmekte, park ve bahçeler tüm yaşları kapsayıcı bir hale gelmektedir. $\mathrm{Bu}$ sayede yaşlı bireylerin hayatın her alanına katılımları desteklenmekte ve bireyler başka bir kişinin desteğine ihtiyaç duymadan aktif ve sağlıklı yaşlanabilmektedir.

Daha aktif ve sağlıklı bir toplumdan bahsedebilmek için yaş dostu çevrelerin oluşturulması elzemdir. Bu kapsamda sürdürülebilir çevrelerin oluşturulması için yasal dayanakların oluşturulması ve sosyal politikalarla bunların uygulamaya yansıtılması önem taşımaktadır. Ancak bütün bunlar gerçekleştirilirken bütün disiplinlerin iş birliği halinde olması sunulacak hizmetlerden maksimum fayda sağlanması açısından önemlidir. Şehir mimarisi planlama ve tasarım sürecine mimar, mühendis, şehir plancısı, sosyolog, sosyal çalışmacı, fizyoterapist vb. meslek grupları ile bu hizmetlerden faydalanacak olan bireylerin de dahil edilmesi sağlanmalıdır. Bu sayede holistik bir bakış açısı ile şehirde yaşayan bütün bireylerin beklenti ve ihtiyaçlarını karşılayan, erişilebilir, yaş dostu kentler ve uygulamalar hayata geçirilebilecektir. 


\section{KAYNAKÇA}

Arslantaş, D., Metintaş, S., Ünsal, A. ve Kalyoncu, C. (2005). Eskişehir'de Yaşlıların Sosyoekonomik Özellikleri ve Sağlık Durumları. Sürekli Tip Eğitimi Dergisi (STED), 14, 113-9.

Aslan, D. (2015). Yaşlı Dostu Kentler. Yaşlı Dostu Kentler Sempozyumu Bildiri Kitabı. (ss. 25-28). http://www.yasliliksurasi.gov.tr/assets/catalogs/yasli-dostu-kentler-sempozyumu-bildiri-kitab.pdf

ASPB Engelli ve Yaşlı Hizmetleri Genel Müdürlügü. (2014. Birleşmiş Milletler Yaşlı İlkeleri. Erişim Tarihi: 8 Ekim 2020, https://ailevecalisma.gov.tr/eyhgm/mevzuat/uluslararasi-mevzuat/

Bilir, N. (2006). Değișen Sağlık Örüntülerinde Halk Sağlığı Çalışanlarının Rolü: Kronik Hastalıklar ve Yaşlılık Sorunları. Toplum Hekimliği Bülteni, 25(3), 1-6.

Buz, S., Ertan Koçak, Y. ve Gözen, Ö. (2018). Türkiye'de Yaşl1lara Sunulan Hizmetlerin Birleşmiş Milletler Yaşlılık İlkeleri Çerçevesinde Değerlendirilmesi: Ankara Örneği. Akademik Sosyal Araştırmalar Dergisi, 6(77), 388-410.

Brdulak, A. (2017). The Concept of a Smart City in the Context of an Ageing Population. Research Journal of the University of Gdansk, 68, 65-75.

European Commission. (2014). Population ageing in Europe. Erişim Tarihi: 20 Haziran 2020, https://ec.europa.eu/research/social-sciences/pdf/policy_reviews/ kina26426enc.pdf

Ferreira, F. R., César, C. C., Camargos, V. P., Lima-Costa, M. F. ve Proietti, F. A. (2010). Aging and Urbanization: the Neighborhood Perception and Functional Performance of Elderly Persons in Belo Horizonte Metropolitan Area Brazil. Journal of Urban Health, 87(1), 54-66.

Gorman, M., Jones, S. ve Turner, J. (2019). Older People, Mobility and Transport in Lowand Middle-Income Countries: A Review of the Research. Sustainability, 11(21), 6157.

Government of Canada. (2020). Enabling Accessibility Fund, Erişim Tarihi: 19 Ekim 2020, https://www.canada.ca/en/employment-social-development/programs/enabling-accessibility-fund.html).

Güler, G., Güler, N., Kocataş, S. ve Akgül, N. (2009). Yaşlıların Sağlık Bakım Gereksinimleri. Cumhuriyet Medical Journal (CMJ), 31(4), 367-373. 
Karadağ, H. ve Akyıldız, N. A. (2019). Avrupa’nın Demografik Dönüşümünde Uuzn Dönem Yaşlı Bakımın Sürdürülebilirliğinin Değerlendirilmesi. Sosyal Politika Çalışmaları Dergisi, 19(44), 571-596.

Mekansal Planlar Yapım Yönetmeliği. (2014). T. C. Resmî Gazete, 29030, 14 Haziran 2014. OECD. (2016). Society at a Glance 216: OECED Social Indicators. Paris: OECD Publishing.

OECD. (2015). Ageing in Cities. Paris: OECD Publishing. Erişim Tarihi: 10 Haziran 2020, https://read.oecd-ilibrary.org/urban-rural-and-regional-development/ageing-in-cities_9789264231160-en\#page3

T.C. Avrupa Birliği Bakanlığı. (2011). 2012 Avrupa Aktif Yaşlanma ve Nesiller Arası Dayanışma Hakkında Bilgi Notu. Ankara. Erişim Tarihi: 6 Haziran 2020, https://www. ab.gov.tr/files/SBYPB/Sosyal\%20Politika\%20ve\%20\%C4\%B0stihdam/aktif_yaslanma_bilgi_notu.pdf

Tutal, O. ve Üstün, B. (2009). Yaşlılık ve Yaş Dostu Kentler: Eskişehir. Yaşlı Sorunları Araştırma Dergisi, 1, 1-23.

TÜİK. (2020a). Adrese Dayalı Nüfus Kayıt Sistemi Sonuçları, 2019. Türkiye İstatistik Kurumu Haber Bülteni, Erişim Tarihi: 20 Haziran 2020, http://www.tuik.gov.tr/ PreHaberBultenleri.do?id=33705

TÜİK. (2020b). Merkezi Dağıtım Sistemi, Erişim Tarihi: 20 Ekim, 2020, https://biruni.tuik. gov.tr $/$ medas $/$ ?kn=95\&locale $=$ tr).

UN. (2017). New Urban Agenda, Erişim Tarihi: 20 Haziran 2020, http://habitat3.org/ wp-content/uploads/NUA-English.pdf

UNDESA. (2018). World Urbanization Prospects 2018: Country Profile, Erişim Tarihi: 2 Eylül 2020, https://population.un.org/wup/Country-Profiles/

UNDESA. (2019a). World Urbanization Prospects The 2018 Revision. Erişim Tarihi: 12 Haziran 2020, https://population.un.org/wup/Publications/Files/WUP2018-Report.pdf

UNDESA. (2019b). World Population Prospects 2019. New York.

UNDESA. (2019c). World Population Prospects 2019 Highlighst. Erişim Tarihi: 12 Haziran 2020, https://www.un.org/en/development/desa/population/publications/ pdf/ageing/WorldPopulationAgeing2019-Highlights.pdf

UNDESA. (2020). Sustainable Development, Erişim Tarihi: 21 Eylül 2020, https://sdgs. un.org/goals/goal1 
UNECE Working Group on Ageing. (2015, February). Policy Brief Innovate and Empowering Strategies for Care. UNECE Policy Brief on Ageing (15), 1-20.

UNECE Working Group on Ageing. (2012, February). Policy Brief Active Ageing. UNECE Policy Brief on Ageing (13), 1-16.

UNECE Working Group on Ageing. (2020, May). Policy Brief Agein in Sustainable and Smart Cities. UNECE Policy Brief on Ageing (24), 1-21.

Ücretsiz veya İndirimli Seyahat Kartları Yönetmeliği. (2014). T. C. Resmî Gazete, 28931, 4 Mart 2014.

Üçok, A. (2018). Yaşlilıkta Aktivite Kuramı ile Yaşamdan Kopma Kuramının Karşılaştırılması. Uluslararası Sosyal Araştırmalar Dergisi, 11(56), 451-456.

Van Hoof, J., Kazak, J. K., Perek-Białas, J. M. ve Peek, S. (2018). The Challenges of Urban Ageing: Making Cities Age-friendly in Europe. International Journal of Environmental Research and Public Health, 15(11), 2473.

WHO. (1997). The Magazine of the World Health Organization: Active Ageing, Erişim Tarihi: Ekim 2020, https://apps.who.int/iris/handle/10665/54909?search-result=true\&query $=$ the + magazine + of + the + world + health + active + ageing\&scope $=\% 2 \mathrm{~F} \& \mathrm{rp}-$ $\mathrm{p}=10$ \&sort_by=score\&order=desc

WHO. (2002), Active Ageing Policy Frame Work, Erişim Tarihi: 8 Mayıs 2020, https://apps. who.int/iris/bitstream/handle/10665/67215/WHO_NMH_NPH_02.8.pdf?sequen$\mathrm{ce}=1$

WHO. (2007). Global Age-friendly Cities: A Guide, Erişim Tarihi: 1 Haziran 2020, http:// www.who.int/ageing/publications/Global_age_friendly_cities_Guide_English.pdf

WHO. (2015). World Report On Ageing And Health, Erişim Tarihi: 1 Haziran 2020, http:// apps.who.int/iris/bitstream/10665/186463/1/9789240694811_eng.pdf?ua=1

WHO. (2018). The Global Network for Age-Friendly Cities and Communities Looking Back Over the Last Decade, Looking Forward to the Next, Erişim Tarihi: 1 Haziran 2020, https://www.who.int/ageing/gnafcc-report-2018.pdf?ua=1

WHO. (2020a). Age-friendly World, Erişim Tarihi: 21 Eylül 2020, https://extranet.who.int/ agefriendlyworld/who-network/

WHO. (2020b). Age-friendly World-Lugaritz Homes: Connecting A Neighbourhood, Erişim Tarihi: 11 Eylül 2020, https://extranet.who.int/agefriendlyworld/afp/lugaritz-homesconnecting-a-neighborhood/ 
SOSYAL POLITIKA

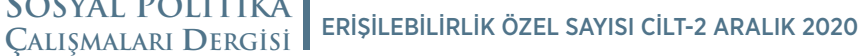

